\title{
Pubic bacterial osteomyelitis in a soccer player: a diagnostic pitfall
}

\author{
Yusuke Ohashi (i), ${ }^{1}$ Shu Koito, ${ }^{2}$ Takashi Matono ${ }^{1}$
}

${ }^{1}$ Department of Infectious Diseases, Aso lizuka Hospital, lizuka, Japan

${ }^{2}$ Department of General Internal Medicine, Aso lizuka Hospital, lizuka, Japan

\section{Correspondence to} Dr Takashi Matono: tmatonoh1@aih-net.com

Accepted 30 November 2021

\section{DESCRIPTION}

A teenage male, without a significant medical history, was admitted to our hospital with a 4-day history of fever, left lower abdominal, left leg and groin pain, and malaise. He was a high-school soccer club member who practised rigorously, but he denied any history of recent skin infection, major traumatic events in the pelvis, abrasions or intravenous drug use. On examination, his vital signs were unremarkable, other than a body temperature of $39.6^{\circ} \mathrm{C}$. He had marked tenderness over the left lower quadrant of the abdomen, and active and passive movement exacerbated the pain in the left leg, especially in the left groin area without radiation. He did not have any murmurs, splinter haemorrhage, Osler nodes or Janeway lesions. Laboratory tests revealed a C reactive protein level of $88.2 \mathrm{mg} / \mathrm{L}$ without leucocytosis. CT and MRI examinations were performed after admission (figures 1 and 2). MRI findings showed a T1 low-signal intensity lesion and T2 high-signal intensity lesion in the left pubis and the blood culture yielded methicillin-sensitive Staphylococcus aureus. Transthoracic echocardiography did not observe any signs of vegetation or abscess, and follow-up blood culture was sterile at 2 days after starting antibiotic administration. These findings were consistent with the diagnosis of acute bacterial osteomyelitis. We initiated intravenous cefazolin administration for 2 weeks, followed by oral clindamycin for 4 weeks considering higher bone penetration capacity. After the antibiotic treatment, the patient fully recovered from the infection without surgery. The pelvic pain disappeared after 1 month and he denied any recurrent symptoms 1 year later.

This case highlights that we should consider several differential diagnoses involving musculoskeletalrelated, hip-related and other aetiologies in athletes

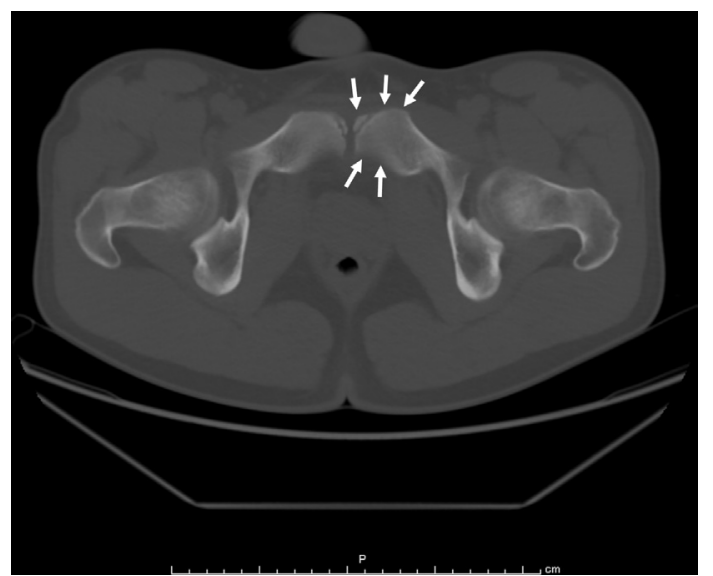

Figure 1 CT scan showing bony margin irregularity.

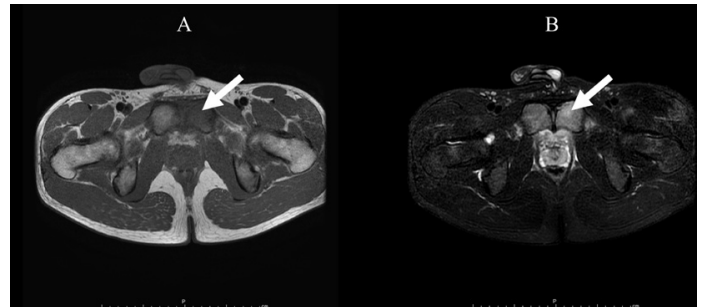

Figure 2 MRI: T1 scan (A) of low-signal intensity and T2 scan (B) of a high-signal intensity lesion in the left pubis.

complaining of groin pain. ${ }^{1}$ Osteitis pubis, a noninfectious chronic inflammatory condition without systemic inflammation, is particularly common in athletes who are involved in leg twisting sports. ${ }^{2-4}$ Its incidence is relatively high; that of osteitis pubis is approximately $0.5 \%-8 \%$ in athletes, and male soccer players could be vulnerable to injuries (annual incidence, 10\%-18\%). ${ }^{4}$ Additionally, approximately $76 \%$ of radiological abnormalities are detected in professional soccer players. ${ }^{5}$ However, acute bacterial osteomyelitis in the pubis is rare $(<1 \%$ of all haematogenous osteomyelitis) but is another essential differential diagnosis as in this case. ${ }^{67}$ Pre-existing trauma or minor injury in the pubic area is considered a possible predisposing factor in athletes, and the haematogenous seeding of transient bacteraemia resulted in pubis osteomyelitis. ${ }^{6}$ S. aureus is the predominant causative pathogen in athletes because it could be related to the localised infection due to bacteraemia. ${ }^{6-8}$ On the other hand, causative pathogens could be polymicrobial in postoperative cases or patients with pelvic malignancies. ${ }^{78}$ The presentation and radiological abnormalities are similar to those of osteitis pubis, which may lead to a diagnostic error. Hence, clinicians should be aware of the infection, and a blood culture or bone biopsy is warranted to distinguish between osteomyelitis and osteitis pubis, particularly in athletes complaining of pelvic pain. ${ }^{9}$

\section{Learning points}

It is imperative to distinguish between acute osteomyelitis and osteitis pubis, especially in athletes complaining of pelvic pain, with blood culture or bone biopsy.

- Staphylococcus aureus is the predominant causative pathogen of acute pubic osteomyelitis in athletes. 
Acknowledgements We wish to thank the physicians, nurses and clinical staff at the Aso lizuka Hospital for their excellent work.

Contributors YO prepared the figures, obtained the written informed consent from the patient, and drafted the manuscript with the help of all the coauthors. SK cared for the patient and reviewed the manuscript. TM helped in writing the manuscript and reviewed the final version.

Funding The authors have not declared a specific grant for this research from any funding agency in the public, commercial or not-for-profit sectors.

Competing interests None declared.

Patient consent for publication Consent obtained directly from patient(s).

Provenance and peer review Not commissioned; externally peer reviewed.

Case reports provide a valuable learning resource for the scientific community and can indicate areas of interest for future research. They should not be used in isolation to guide treatment choices or public health policy.

\section{ORCID iD}

Yusuke Ohashi http://orcid.org/0000-0003-3885-2252

\section{REFERENCES}

1 Bisciotti GN, Auci A, Di Marzo F, et al. Groin pain syndrome: an association of different pathologies and a case presentation. Muscles Ligaments Tendons J 2015;5:214-22.

2 Choi H, McCartney M, Best TM. Treatment of osteitis pubis and osteomyelitis of the pubic symphysis in athletes: a systematic review. Br I Sports Med 2011;45:57-64.

3 Yax J, Cheng D. Osteomyelitis pubis: a rare and elusive diagnosis. West J Emerg Med 2014;15:880-2.

4 Via AG, Frizziero A, Finotti P, et al. Management of osteitis pubis in athletes: rehabilitation and return to training — a review of the most recent literature. Open Access J Sports Med 2019:10:1-10.

5 Harris NH, Murray RO. Lesions of the symphysis in athletes. Br Med J 1974;4:211-4.

6 Ukwu HN, Graham BS, Latham RH. Acute pubic osteomyelitis in athletes. Clin Infect Dis 1992;15:636-8

7 Ross JJ, Hu LT. Septic arthritis of the pubic symphysis: review of 100 cases. Medicine 2003;82:340-5

8 Becker A, Triffault-Fillit C, Valour F, et al. Pubic osteomyelitis: epidemiology and factors associated with treatment failure. Med Mal Infect 2020;50:684-8.

9 Karpos PA, Spindler KP, Pierce MA, et al. Osteomyelitis of the pubic symphysis in athletes: a case report and literature review. Med Sci Sports Exerc 1995;27:473-9.

Copyright 2021 BMJ Publishing Group. All rights reserved. For permission to reuse any of this content visit

https://www.bmj.com/company/products-services/rights-and-licensing/permissions/

BMJ Case Report Fellows may re-use this article for personal use and teaching without any further permission.

Become a Fellow of BMJ Case Reports today and you can:

- Submit as many cases as you like

- Enjoy fast sympathetic peer review and rapid publication of accepted articles

- Access all the published articles

Re-use any of the published material for personal use and teaching without further permission

\section{Customer Service}

If you have any further queries about your subscription, please contact our customer services team on +44 (0) 2071111105 or via email at support@bmj.com.

Visit casereports.bmj.com for more articles like this and to become a Fellow 